\title{
Corporate Governance and Firm's Performance: Empirical Evidence from Vietnam
}

\author{
VÕ HỒNG ĐỨC \\ Economic Regulation Authority, Perth, Australia \\ Ho Chi Minh City Open University \\ Email: duc.vo@erawa.com.au \\ PHAN BÙI GIA THỦY \\ Open University, Ho Chi Minh City, Vietnam \\ Email: stephen_chau84@yahoo.com
}

\begin{abstract}
ARTICLE INFO
ABSTRACT

Article history:

Received:

13 March 2013

Received in revised form

22 April 2013

Accepted:

25 September 2013

This empirical study, the first of its kind, seeks to quantify the relationship between corporate governance and the performance of firms in Vietnam. The authors undertook an intensive review of literature to identify a range of elements that contribute to overall corporate governance. In this study, corporate governance is considered to consist of the following elements: (i) the size of the board; (ii) the presence of female board members; (iii) the duality of the CEO; (iv) the education level of board members; (v) the working experience of the board; (vi) the presence of independent (outside) directors; (vii) the compensation of the board; (viii) the ownership of the board; and (ix) block holders. Employing the Feasible Generalized Least Squares (FGLS) technique on 77 listed firms trading over the period from 2006 to 2011, this study finds that elements of corporate governance such as the presence of female board members, the duality of the CEO, the working experience of board members, and the

Keywords:

corporate governance, ownership structure, firm's performance, listed firms,

Vietnam compensation of board members have positive effects on the performance of firms, as measured by the return on asset (ROA), while board size produces negative ones. The results also show that ownership of board members has a non-linear relationship with firm's performance.
\end{abstract}




\section{INTRODUCTION}

Many empirical studies had been conducted over the last two decades to investigate a relationship between corporate governance and firm's performance in the world. However, similar studies in the context of Vietnam are very rare. In Vietnam, studies on this topic are mainly conducted in a qualitative form by referring to the history of corporate governance in Vietnam using legal documents.

As such, this study aims to quantify the contribution of the corporate governance to the firm's performance of listed companies in Vietnam. Literature review and previous empirical studies from overseas have focused on developing a research framework and hypotheses concerning the relationship between corporate governance and firm's performance. Those have indicated that corporate governance can be measured through the following elements: (i) board's size; (ii) female board members; (iii) the duality of the CEO; (iv) educational level of board members; (v) board's working experience; (vi) independent (outside) directors; (vii) board's compensation; (viii) board's ownership; and (ix) block holders. In addition, firm's performance is measured by the return on asset, known as the ROA ratio.

This study has examined various research hypotheses based on a sample of 77 listed companies in HCMC Stock Exchange (HOSE) for the period of 6 years from 2006 to 2011, the longest possible data set when this study was conducted. The Feasible Generalized Least Square (FGLS) technique is adopted together with other econometric techniques in this paper.

\section{LITERATURE REVIEW AND RESEARCH HYPOTHESES}

Evidence from previous empirical studies from academic literature has confirmed the effect of corporate governance on firm's performance. A literature review from relevant academic studies has indicated the following characteristics applied to corporate governance such as (i) board's size; (ii) female board members; (iii) duality; (iv) educational level of board members; (v) board's working experience; (vi) independent directors; (vii) board's compensation; (viii) board's ownership; and (ix) block holders. Each of these characteristics will be discussed in details and in turn below.

In this study, a research framework is presented in Figure 1 below. 


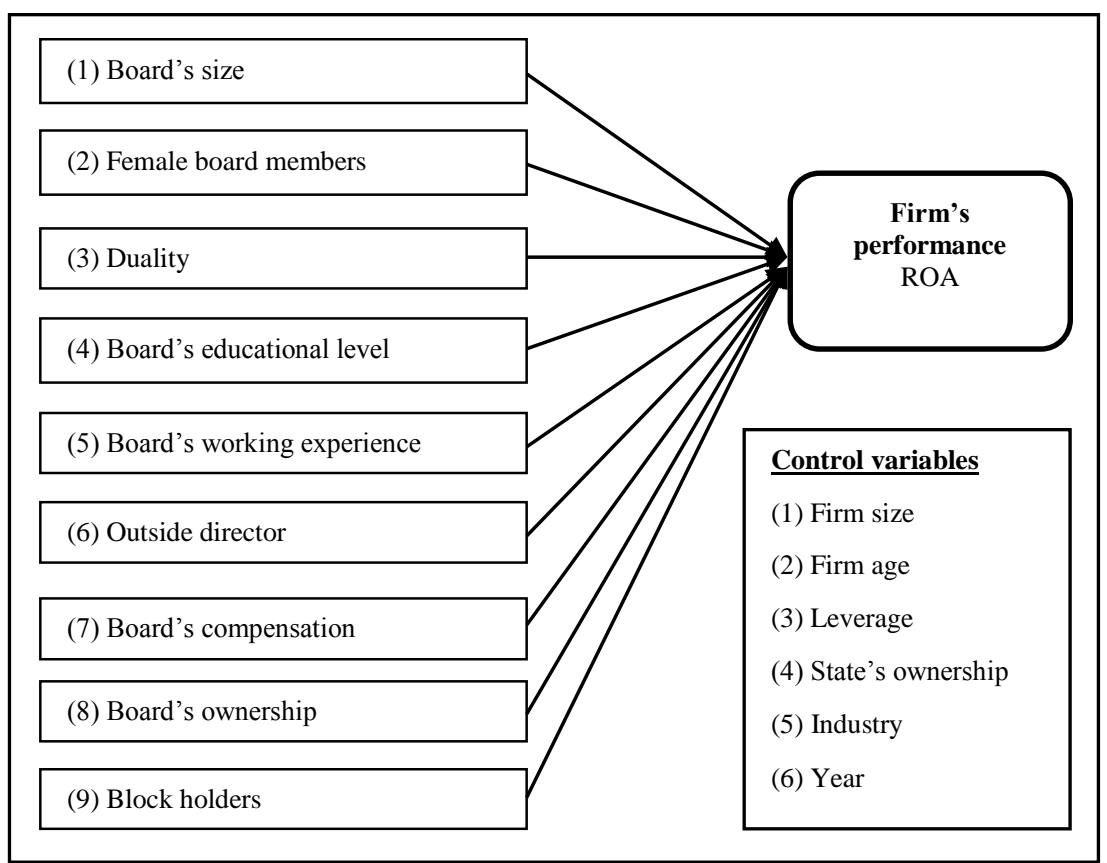

Figure 1: Research Framework

\section{a. Board's Size:}

In relation to a relationship between board's size and firm's performance, there are two distinct schools of thoughts. The first school argued that a smaller board size will contribute more to the success of a firm (Lipton \& Lorsch, 1992; Jensen, 1993; Yermack, 1996). However, the second school considered that a large board's size will improve firm's performance (Pfeffer, 1972; Klein, 1998; Coles et al., 2008). These studies indicate that a large board will support and advise firm management more effectively because of a complex of business environment and an organizational culture (Klein, 1998). Moreover, a large board size will gather much more information. As a result, a large board size appears to be better for firm performance (Dalton et al., 1999).

Truong et al. (1998) observed that in Vietnam, there is a significant difference in management culture compared to international practices. For example, they concluded that Vietnamese management does not appear to share managerial power. This philosophy reflects a "gap of power" culture in Vietnamese companies. This culture in Vietnam is completely different from the principles of working as a group and management delegation. Hence, these authors concluded that when board's size 
increases, delegation will be reduced. On the ground of this study, a research hypothesis is formed as below:

Hypothesis H1: There is a negative relationship between board's size and firm's performance.

\section{b. Female Board Members:}

Female board members are examined very often in empirical studies. The female board members reflect a diversified characteristic of the board (Dutta \& Bose, 2006). In addition, Smith et al. (2006) considered three different reasons to recognize the importance of females in the board. First, they usually have a better understanding of a market in comparison with male members. Therefore, this understanding will enhance the decisions made by the board. Second, female board members will bring better images in the perception of the community for a firm and this will contribute positively to firm's performance. Third, other board members will enhance understanding from business environment when female board members are appointed. Moreover, this study also indicated that female board members can positively affect career development of junior female staff in a business. As a result, firm's performance is improved directly and indirectly with the presence of female board members.

Hypothesis $\mathrm{H} 2$ : There is a positive relationship between female board members and firm's performance.

\section{c. Duality of the CEO:}

Even though empirical studies cannot obtain a consensus on a contribution of duality to firm's performance, there is an agreement between shareholders, institutional investors, and policymakers that a chairman/chairwoman of a board and the CEO should not be one and the same. In their study, Dahya et al. (2009) presented that, between 1994 and 2003, policymakers in 15 advanced nations and the United Kingdom recommended a chairman/chairwoman of a board and CEO should not be one and the same. In Europe, $84 \%$ of firms separate the roles of a board chairperson and a CEO of a firm (Heidrick \& Struggles, 2009). According to Hewa-Wellalage \& Locke (2011), in Sri Lanka, the Sri Lankan Code of Best Practice on Corporate Governance emphasizes a balance of power within a firm to minimize anyone's influence on decision-making process. These rules provided recommendation that in the presence of a duality in a firm, a number of independent directors in a board should be a majority to balance an effective and efficient operation of a board. 
In recognition of the importance of the separate responsibility between a chairman and a CEO, for the period from 1999 to 2003, many businesses had altered their existing structure of duality to non-duality structure (Chen, Lin \& Yi, 2008). These authors considered that, in many businesses with duality structure, there has been an abuse of power at the expense of the company and the shareholders. In Vietnam, Ministry of Finance (2012) stipulated that "a chairman/chairwoman of a board should not be in the position of the CEO of a company unless this duality is approved by the annual general meeting of shareholders". In addition, Fama \& Jensen (1983) and Jensen (1993) concluded that duality would reduce board's supervision to a company management. This reduction results in an increase in agency cost. As a result, a research hypothesis is developed as follows:

Hypothesis H3: A duality negatively affects firm's performance.

\section{d. Board's Educational Level:}

One of the roles of a board is to act as an internal supervisor of corporate governance of a firm (Fama, 1980). A board is also a control system in a business (Fama \& Jensen, 1983). A board of directors that supervises management decisions efficiently will improve firm's performance. Doing so requires each board member to be fully equipped with management knowledge such as finance, accounting, marketing, information system, legal issues and other related areas to decision-making process. This requirement implies that quality of each board member will contribute significantly and positively to management decision, which is then translated into firm's performance (Nicholson \& Kiel, 2004; Fairchild \& Li, 2005; Adams \& Ferreira, 2007).

On the grounds of the above analysis, the following research hypothesis is developed:

Hypothesis H4: Board's educational level will positively contribute to firm's performance.

\section{e. Board's Experience:}

It is argued that board members with higher age average will have much more experience compared to younger age average. This experience will positively contribute to firm's performance. However, an older board member appears to be more aggressive and dictatorial with decisions. These characteristics of board members may result in a risky decision which may undermine firm's performance (Carlson \& Karlsson, 1970). In addition, board member with high average age may face a more limited pressure to a 
changing business environment and this will hinder the implementation of more strategic decisions (Child, 1975).

Even though there has been a conflicting view on the relationship between board's level of experience and firm's performance, a theory on restrained resources argues that board members with more experience will cope better with business environment by working well in a group which will contribute positively to firm's performance (Wegge et al., 2008).

Hypothesis H5: Board's level of experience is positively correlated with firm's performance.

\section{f. Board's Independent Directors:}

Many empirical studies agreed on an importance of independent directors to success of a firm. For example, Elloumi \& Gueyié (2001) concluded that firms with high ratio of independent directors in a board face less frequently financial pressure. In addition, when business environment is getting worse, firms with many independent directors have a lower probability to file for bankruptcy (Daily et al., 2003). As such, a research hypothesis is as below.

Hypothesis H6: Independent directors will contribute positively to firm's performance.

\section{g. Board's Compensation:}

One of the key objectives in modern corporate governance is to deal with agency problem (Jensen \& Meckling, 1976). A representative agency theory considers that goals adopted by firm's management and shareholders are generally not similar. As such, shareholders should attach their financial benefits to compensation paid to firm's management. Once management behavior is unclear, compensation is a corporate governance mechanism to encourage management to run a firm in the interest of shareholders. This link will resolve an agency issue between management and shareholders and contribute positively to firm's performance (Jensen \& Murphy, 1990; Mehran, 1995).

Hypothesis H7: There is a positive correlation between management's compensation to firm's performance.

\section{h. Board's Ownership:}


Brickley et al. (1988) concluded that board's ownership is an encouragement to board members. This encouragement will help board's members supervise management in a more efficient way. In consistence with this view, Jensen \& Murphy (1990) and Chung \& Pruitt (1996) suggested that board's ownership will improve firm's performance. Mehran (1995) presented empirical evidence of a positive correlation between board's ownership and firm's performance.

Hypothesis H8a: Board's ownership is positively related to firm's performance.

In addition, other empirical studies such as Gedajlovic \& Shapiro (1998) and Bhabra et al. (2003) have also presented a non-linear relationship between board's ownership and firm's performance. Fama \& Jensen (1983) argued that contribution of board's ownership is considered as a "two-edged knife" in which an optimal level of board's ownership that contributes positively to firm's performance could be found. On the grounds of the above analysis, a research hypothesis is developed as below.

Hypothesis H8b: There is a non-linear relationship between board's ownership and firm's performance.

\section{i. Block holders:}

A direct control of a free cash flow is to be block holders who own majority of shares of a firm. Empirical studies on block holders by Shleifer \& Vishny (1997) concluded that, to a certain extent, block holders contribute to supervisory activities of firm's management. On the other hand, there exists agency cost related to block holders. First, small shareholders will bear serious consequences from block holders who may abuse the power in running a business. Second, a strict control from block holders to firm's management will hinder firm's performance. Firm's management will become inflexible with changing business environment. Decision-making process is no longer an initiative from firm's management, and these results in a lower firm's performance (Burkart et al., 1997; Myers, 2000).

In spite of conflicting views on an effect of block holders on firm's performance, many empirical studies have recognized this importance. In particular, block holders play an important role in the corporate governance because they have relevant skills, time and attention to firm's performance. Denis \& McConnell (2003) and Becker et al. (2011) considered that centralizing managerial power in block holding individuals will generally affect firm's performance positively. This is because block holders will help 
minimize agency cost in firm's performances. Thus, a research hypothesis is developed as below.

Hypothesis H9: Firm's performance is enhanced with the presence of block holders.

\section{MEASUREMENT OF VARIABLES}

Variables used in this empirical study comprise: (1) dependent variable (firm's performance); (2) independent variables; and (3) control variables. Concepts and measurements of these variables are summarized in Table 1 below.

Table 1: Concepts and Measurements of Variables

\begin{tabular}{|c|c|c|}
\hline Variables & Definition & Measurement \\
\hline \multicolumn{3}{|c|}{ Dependent variable } \\
\hline$R O A$ & Return on asset & $\begin{array}{l}\text { (Earnings Before Tax and Interest)/Total } \\
\text { Assets }\end{array}$ \\
\hline \multicolumn{3}{|c|}{ Explanatory variables } \\
\hline Board size & Board members & $\begin{array}{l}\text { Number of inside and outside directors on } \\
\text { the board }\end{array}$ \\
\hline Gender & Female board members & Numbers of women present on the board \\
\hline Duality & CEO Dual & $\begin{array}{l}\text { Coded " } 1 \text { " if Chairperson also works as a } \\
\text { CEO and " } 0 \text { " otherwise }\end{array}$ \\
\hline$E d u$ & Board's educational level & $\begin{array}{l}\text { Number of directors holding postgraduate } \\
\text { degrees }\end{array}$ \\
\hline Board Age & Board's working experience & Average age of all directors on the board \\
\hline OutDir & Outside director & $\begin{array}{l}\text { Number of non-executive directors on the } \\
\text { board }\end{array}$ \\
\hline Comp & Board's compensation & $\begin{array}{l}\text { Average compensation of all directors on } \\
\text { the board, natural logarithm is taken after } \\
\text { adding } 1 \text { to all firm to control firms that } \\
\text { didn't pay compensation }\end{array}$ \\
\hline Own & Board's ownership & $\begin{array}{l}\text { Ratio of shares held by director divided by } \\
\text { total outstanding shares }\end{array}$ \\
\hline Block & Block holders & $\begin{array}{l}\text { Code " } 1 \text { " if fraction of total outstanding } \\
\text { shares held by block holders is greater }\end{array}$ \\
\hline
\end{tabular}


than 5\% (not considering state ownership) and " 0 " otherwise

\section{Control variables}

\begin{tabular}{|c|c|c|}
\hline Firm Size & Firm size & $\begin{array}{l}\text { Natural logarithm of book value of total } \\
\text { assets }\end{array}$ \\
\hline Firm Age & Years of establishment & $\begin{array}{l}\text { Natural logarithm of years since } \\
\text { establishment }\end{array}$ \\
\hline State & State ownership & $\begin{array}{l}\text { Code " } 1 \text { " if Government is owner and " } 0 \text { " } \\
\text { otherwise }\end{array}$ \\
\hline Leverage & Financial leverage & Ratio of total debt divided by equity \\
\hline Industry & Industry effect & Industry dummies \\
\hline Year & Fiscal year & Year dummies \\
\hline
\end{tabular}

\section{CHARACTERISTICS OF THE DATA SAMPLE}

The sample comprises 122 firms listed in HOSE in the period from 2006 to 2011 inclusive. This sample does not include banks, financial companies, insurance firms and investment funds due to significant difference of the capital structures and operations' requirements. It is noted that formats of annual reports and financial statements of these 122 listed firms are not similar. Hence, data missing is unavoidable. As a result, listed firms that lack any required data are excluded from the final sample of the study. Our final sample only includes 77 listed firms with the total of 325 observations.

This research sample includes listed companies in seven different industries: (i) Manufacturing; (ii) Mining, Quarrying, and Oil and Gas; (iii) Construction; (iv) Wholesale and Retail Trade; (v) Agriculture, Forestry, Fishing and Hunting; (vi) Utilities and (vii) Transportation and Warehousing. Classification of these seven industries is based on the North American Industrial Classification System - NAICS (U.S. Census Bureau, 2008).

Table 2: Descriptive Statistics of Variables

\begin{tabular}{lcccc}
\hline \multicolumn{1}{c}{ Variables } & Mean & Std. Dev. & Minimum & Maximum \\
\hline Board size & 5.85 & 1.29 & 5 & 11 \\
Gender & 0.88 & 1.04 & 0 & 7
\end{tabular}




\begin{tabular}{lcccc} 
Duality & $51.4 \%$ & $50.1 \%$ & 0 & 1 \\
Edu & 1.48 & 1.31 & 0 & 6 \\
Board Age & 48.4 & 4.2 & 35.8 & 61.6 \\
OutDir & 2.67 & 1.34 & 0 & 7 \\
Comp & 98.38 & 104.92 & 0 & 666.11 \\
Own & $9.8 \%$ & $13.2 \%$ & $0.0 \%$ & $58.1 \%$ \\
Block & $65.8 \%$ & $47.5 \%$ & 0 & 1 \\
ROA & $11.8 \%$ & $7.8 \%$ & $-19.2 \%$ & $39.5 \%$ \\
\hline
\end{tabular}

Source: Authors' calculations

Figure 2 below presents a correlation between board's ownership and firms' performance for 77 listed firms in HOSE for the 6-year period from 2006 to 2011.

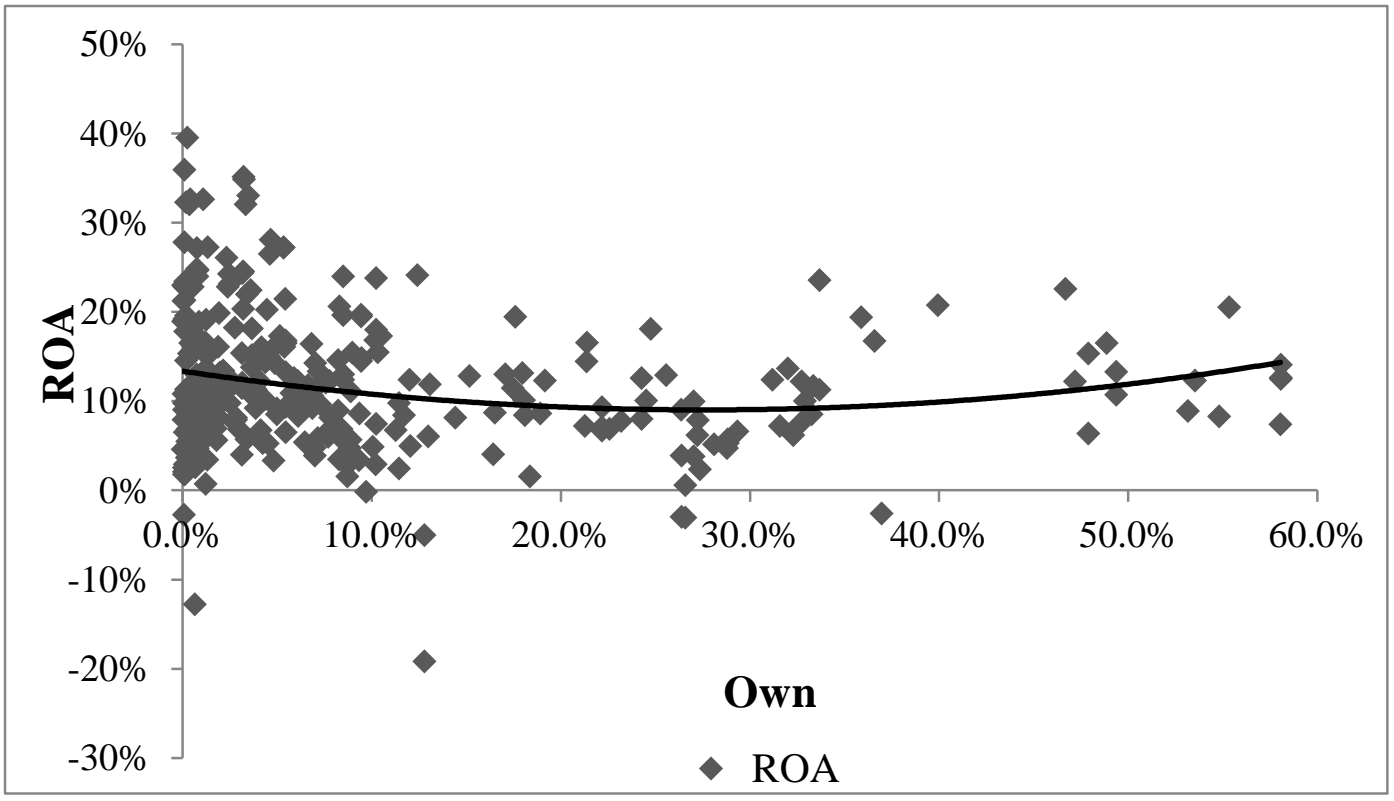

Figure 2: A Correlation between Board's Ownership and Firm's Performance

Figure 2 shows that a non-linear relationship between board's ownership (proxied by Own) and firm's performance (proxied by ROA) does exist. The ratio ROA will decrease when board's ownership increases from $0 \%$ to approximately $20 \%-25 \%$. After that, ROA will increase. This observation will be tested in an empirical outcome of this study. 


\section{RESULTS}

Table 3 indicates a correlation matrix between dependent variable and independent variables. The outcomes show that there is no significant correlation among independent variables. A maximum of a correlation coefficient of 0.47 is found via a correlation between firm's size and board's compensation. In addition, Table 3 also presents the VIF factor (Variance Inflation Factor), an important index representing the multicollinearity in the research model. The maximum of this VIF is at 1.69 which implies that multicollinearity is not significant in this study.

Table 3: A Correlation Matrix among Variables

\begin{tabular}{|c|c|c|c|c|c|c|c|c|c|c|c|c|c|c|c|c|}
\hline \multicolumn{2}{|c|}{ Variables } & (1) & (2) & (3) & (4) & (5) & (6) & (7) & (8) & (9) & (10) & (11) & (12) & (13) & (14) & VIF \\
\hline (1) & ROA & 1 & & & & & & & & & & & & & & - \\
\hline (2) & Board size & 0.02 & 1 & & & & & & & & & & & & & 1.46 \\
\hline (3) & Gender & 0.30 & 0.37 & 1 & & & & & & & & & & & & 1.38 \\
\hline (4) & Duality & 0.17 & 0.10 & 0.24 & 1 & & & & & & & & & & & 1.38 \\
\hline (5) & Edu & 0.08 & 0.20 & 0.11 & 0.08 & 1 & & & & & & & & & & 1.41 \\
\hline (6) & Board Age & 0.21 & -0.04 & -0.03 & -0.14 & -0.14 & 1 & & & & & & & & & 1.20 \\
\hline (7) & OutDir & -0.13 & 0.28 & -0.07 & -0.32 & 0.06 & 0.04 & 1 & & & & & & & & 1.34 \\
\hline (8) & Comp & 0.24 & 0.04 & 0.13 & 0.05 & 0.29 & 0.11 & $0 . \overline{03}$ & 1 & & & & & & & 1.51 \\
\hline (9) & Own & -0.10 & 0.03 & 0.13 & 0.20 & -0.23 & -0.24 & 0.04 & -0.21 & 1 & & & & & & 1.69 \\
\hline (10) & Block & 0.04 & 0.18 & 0.17 & 0.18 & 0.05 & -0.05 & 0.12 & 0.10 & 0.36 & 1 & & & & & 1.37 \\
\hline (11) & Firm Size & 0.02 & -0.02 & -0.01 & 0.13 & 0.32 & -0.04 & 0.04 & 0.47 & -0.04 & -0.01 & 1 & & & & 1.59 \\
\hline (12) & Firm Age & 0.12 & 0.05 & 0.12 & 0.14 & 0.01 & 0.16 & 0.09 & 0.14 & 0.02 & -0.02 & 0.04 & 1 & & & 1.17 \\
\hline (13) & State & 0.10 & 0.17 & -0.12 & -0.03 & 0.25 & 0.19 & 0.03 & 0.20 & -0.45 & -0.22 & 0.10 & 0.21 & 1 & & 1.54 \\
\hline (14) & Leverage & -0.38 & -0.10 & -0.18 & 0.09 & -0.08 & -0.06 & 0.00 & 0.01 & 0.10 & -0.16 & 0.29 & -0.11 & 0.02 & 1 & 1.27 \\
\hline
\end{tabular}

Source: Authors' calculations

In Table 4, Panel A presents the outcomes from the White test and Panel B presents the outcomes for the Breusch-Godfrey test. The Prob. Chi-Square in Panel A is greater than 5\% and the Prob. Chi-Square in Panel B is smaller than 5\%. These tests indicate that, in the adopted empirical model, there is no evidence of heteroskedasticity. However, the model has an autocorrelation problem. 


\section{Table 4: Tests of Heteroskedasticity and Autocorrelation}

Panel A The White Test:

\begin{tabular}{crll} 
F-statistic & 1.2758 & Prob. F(25,299) & 0.1744 \\
Obs*R-squared & 31.3272 & Prob. Chi-Square(25) & 0.1784 \\
\hline
\end{tabular}

Panel B The Breusch-Godfrey Test:

\begin{tabular}{ccll} 
F-statistic & 57.5790 & Prob. F(1,298) & 0.0000 \\
Obs*R-squared & 57.6274 & Prob. Chi-Square(1) & 0.0000 \\
\hline
\end{tabular}

Source: Authors' calculations

After considering the extent to which variables suffer from multicolleniarity, heteroskedasticity and autocorrelation, a regression is conducted. Table 5 presents the regression outcomes using the FGLS method. Wooldridge (2002) considers that the FGLS method is very useful to control heteroskedasticity and autocorrelation.

Table 5 presents the findings of the two models using the FGLS method. Model (1) includes all variables represented for corporate governance which are used to explain the linear relationship between corporate governance and firm's performance.

\section{Model (1)}

ROA $=\beta_{0}+\beta_{1}$ Boardsize $+\beta_{2}$ Gender $+\beta_{3}$ Duality $+\beta_{4}$ Edu $+\beta_{5}$ BoardAge $+\beta_{6}$ OutDir $+\beta_{7}$ Comp $+\beta_{8}$ Own $+\beta_{9}$ Block $+\beta_{10}$ FirmSize $+\beta_{11}$ FirmAge $+\beta_{12}$ Leverage $+\beta_{13}$ State + $\beta_{14}$ Industry $_{i j}+\beta_{15}$ Year $_{i j}+\varepsilon_{i}$

As presented in Figure 2, there is a possibility that the relationship between board's ownership and firm's performance is non-linear. As a result, in Model (2), the variable $O w n^{2}$ (a square of a board's ownership) is added into the model to replace for the variable Own as stated in Model (1).

\section{Model (2)}

ROA $=\beta_{0}+\beta_{1}$ Boardsize $+\beta_{2}$ Gender $+\beta_{3}$ Duality $+\beta_{4}$ Edu $+\beta_{5}$ BoardAge $+\beta_{6}$ OutDir $+\beta_{7}$ Comp $+\beta_{8}$ Own $+\beta_{9}$ Own ${ }^{2}+\beta_{10}$ Block $+\beta_{11}$ FirmSize $+\beta_{12}$ FirmAge $+\beta_{13}$ Leverage + $\beta_{14}$ State $+\beta_{15}$ Industry $_{i j}+\beta_{16}$ Year $_{i j}+\varepsilon_{\mathrm{i}}$

In both models, this empirical study uses moderating variables including the size of a firm (Firm Size); the number of years of establishment (Firm Age); financial leverage (Leverage); ownership by the government (State); Industry; and a fiscal year (Year). The 
findings provide the basis for accepting or rejecting all research hypotheses. Table 5 below presents the outcomes.

Table 5: FGLS Regression Results

\begin{tabular}{|c|c|c|c|c|}
\hline \multirow{2}{*}{ Independent variables } & \multicolumn{4}{|c|}{ Dependent variable: ROA } \\
\hline & Model (1) & & Model (2) & \\
\hline Constant & -0.0753 & & -0.0410 & \\
\hline Board size & -0.0065 & $*$ & -0.0052 & \\
\hline Gender & 0.0177 & $* * *$ & 0.0156 & $* * *$ \\
\hline Duality & 0.0243 & $* * *$ & 0.0281 & $* * *$ \\
\hline Edu & -0.0060 & & -0.0076 & $* *$ \\
\hline Board Age & 0.0020 & $*$ & 0.0016 & \\
\hline OutDir & 0.0012 & & 0.0013 & \\
\hline Comp & 0.0119 & $* * *$ & 0.0131 & $* * *$ \\
\hline Own & 0.0229 & & -0.1996 & $*$ \\
\hline Own ${ }^{2}$ & & & 0.4544 & $* *$ \\
\hline Block & -0.0110 & & -0.0091 & \\
\hline Firm Size & 0.0063 & & 0.0046 & \\
\hline Firm Age & 0.0042 & & 0.0065 & \\
\hline State & 0.0091 & & 0.0055 & \\
\hline Leverage & -0.0210 & $* * *$ & -0.0208 & $* * *$ \\
\hline Industry & control & & control & \\
\hline Year & control & & control & \\
\hline No. of obs & 325 & & 325 & \\
\hline $\mathrm{R}^{2}$ adj. & $25.42 \%$ & & $27.02 \%$ & \\
\hline Durbin-Watson & 1.76 & & 1.78 & \\
\hline
\end{tabular}

$* * * \mathrm{p}<0.01 ; * * \mathrm{p}<0.05 ; * \mathrm{p}<0.10$

Source: Authors' calculations 


\section{RESEARCH FINDINGS AND IMPLICATIONS FOR VIETNAM}

Using the FGLS method, the research finds various results indicating the relationship between variables in the model. The relationship could be: (i) positively correlated; (ii) negatively correlated; (iii) non-linearly correlated; and no correlation at all.

First, four characteristics of the corporate governance, including female board members, duality of the CEO, board's working experience, and board's compensation all have positive correlations with firm's performance. In particular, this study finds that female board members represent a diversification of board's membership and this diversified nature will contribute positively to firm's performance. In addition, when the board's chairperson is also the CEO of a firm (known as a duality of the CEO), firm's performance is improved. This finding is supported by managerial theory. This study also finds empirical evidence to support the view that experienced board members will contribute positively to firm's performance and board's compensation, being the link between the benefits of shareholders and that of firm's management and will also contribute positively to firm's performance.

The results also support the view that a board size will contribute negatively to firm's performance for Vietnam's listed firms. Interestingly, the study finds that when board's ownership varies within the $0 \%-22 \%$ range, there is a reduction in firm's performance. After that, when board's ownership exceeds $22 \%$, this increase will result in an increase in firm's performance. This outcome confirms that there is a non-linear relationship between corporate governance and board's ownership.

However, there is no link between independent directors and firm's performance. In addition, the relationship between other board's characteristics such as educational level of board's members and firm's performance cannot be concluded from this study.

On the grounds of the findings from this empirical study of the contribution of corporate governance to firm's performance, the following conclusions are reached.

First, the Ministry of Finance (2012) stipulated that a number of board's members should vary between 5 and 11 members. This study indicates that board's size reduces firm's performance. As such, it is appropriate to reduce the number of board members.

Second, during the process in which data was collected, it is noted that there are many listed firms without data of board's ownership. From the findings of this study, board's ownership will contribute positively to firm's performance. As a result, it is argued that data on business operations from listed firms must be provided on a transparent basis. 
This empirical study aims to provide empirical evidence for listed firms in enhancing their understanding in relation to the development of a corporate governance mechanism. Thus, listed companies are now provided with evidence to set up a flexible, dynamic and efficient mechanism. Some specific lessons can be summarized as below.

- There should not be too many members on the board because a larger board's size will contribute negatively to firm's performance.

- Board should appoint female board members because these females will make a significant contribution to firm's performance.

- The outcomes also indicate that board's compensation will positively contribute to firm's performance. Therefore, it is necessary for listed firms to consider an appropriate and competitive compensation level of board's members. The compensation will provide a better link between shareholders and firm's management and this link will enhance firm's performance to maximize shareholders' value

\section{References}

Adams, R., B. \& D. Ferreira (2007), “A Theory of Friendly Boards”, Journal of Finance, 62(1), 217 250.

Becker, B. et al. (2011), "Estimating the Effects of Large Shareholders Using a Geographic Instrument", Journal of Financial and Quantitative Analysis, 46(4), 907-942.

Bhabra, G., S. et al. (2003), “Corporate Governance in Singapore: The Impact of Directors' Equity Ownership", Advances in Financial Economics, 8, 29-46.

Brickley, J. A., R. C. Lease \& C. Smith, Jr. (1988), “Ownership Structure and Voting on Antitakeover Amendments”, Journal of Financial Economics, 20, 267-291.

Burkart, M., D. Gromb \& F. Panunzi (1997), "Large Shareholders, Monitoring, and the Value of the Firm”, The Quarterly Journal of Economics, 112(3), 693-728.

Carlson, R. \& K. Karlsson (1970), “Age, Cohorts, and the Generation of Generations”, American Sociological Review, 35(4), 710-718.

Chen, C. W., J. B. Lin \& B. Yi (2008), “CEO Duality and Firm Performance: An Endogenous Issue”, Corporate Ownership and Control, 6(1), 58-65.

Child, J. (1975), "Managerial and Organizational Factors Associated with Company Performance Part II. A Contingency Analysis", Journal of Management Studies, 12, 12-27.

Chung, K. H. \& S. W. Pruitt (1996), "Executive Ownership, Corporate Value, and Executive Compensation: A Unifying Framework”, Journal of Banking and Finance, 20(7), 1135-1159. 
Coles, J. L., N. D. Daniel \& L. Naveen (2008), “Boards: Does One Size Fit All?” Journal of Financial Economics, 87(2), 329-356.

Dahya, J., L. G. Garcia \& J. van Bommel (2009), “One Man Two Hats: What's All the Commotion!” The Financial Review, 44(2), 179-212.

Dalton, D. R. et al. (1999), "Number of Directors and Financial Performance: A Meta-Analysis", The Academy of Management Journal, 42(6), 674-686.

Daily, C. M., D. R. Dalton \& A.A. Cannella (2003), “Corporate Governance: Decades of Dialogue and Data", The Academy of Management Review, 28(3), 371-382.

Denis, D. K. \& J. McConnell (2003), “International Corporate Governance”, Journal of Finance and Quantitative Analysis, 38(1), 1-36.

Dutta, P. \& S. Bose (2006), "Gender Diversity in the Boardroom and Financial Performance of Commercial Banks: Evidence from Bangladesh", The Cost and Management, 34(6), 70-74.

Elloumi, F. \& J.P. Gueyié (2001), "Financial Distress and Corporate Governance: An Empirical Analysis", Corporate Governance, 1(1), 15-23.

Fama, E. F. (1980), “Agency Problems and the Theory of the Firm”, Journal of Political Economy, 88(2), 288-307.

Fama, E., F. \& M. C. Jensen (1983), "Separation of Ownership and Control”, Journal of Law and Economics, 15(2), 301-325.

Fairchild, L. \& j. Li (2005), "Director Quality and Firm Performance”, The Financial Review, 40(2), 257-279.

Gedajlovic, E. R. \& D. M. Shapiro (1998), "Management and Ownership Effects: Evidence from Five Countries", Strategic Management Journal, 19(6), 533-553.

Heidrick \& Struggles (2009), Corporate Governance Report 2009 - Boards in turbulent times, Heidrick and Struggles International, Inc.

Hewa-Wellalage, N. \& S. Locke (2011), "Does CEO Duality is Really Matter? Evidence from an Emerging Market", Corporate Ownership and Control, 8(4), 112-122.

Jensen, M. C. (1993), “The Modern Industrial Revolution, Exit, and the Failure of Internal Control Systems", The Journal of Finance, 48(3), 831-880.

Jensen, M. C. \& W. H. Meckling (1976), "Theory of the Firm Managerial Behavior, Agency Costs and Ownership Structure", Journal of Financial Economics. 3(4), 305-360.

Jensen, M. C. \& K. J. Murphy (1990), "Performance Pay and Top-Management Incentives", Journal of Political Economy, 98(2), 225-264.

Klein, A. (1998), "Firm Performance and Board Committee Structure", Journal of Law and Economics, 41(1), 275-303. 
Lipton, M. \& J. W. Lorsch (1992), "A Modest Proposal for Improved Corporate Governance”, Business Lawyer, 48(1), 59-77.

Mehran, H. (1995), "Executive Compensation Structure, Ownership and Firm Performance”, Journal of Financial Economics, 38(2), 163-184.

Myers, S. C. (2000), “Outside Equity”, The Journal of Finance, 55(3), 1005-1037.

Nicholson, G. J. \& G. C. Kiel (2004), "Breakthrough Board Performance: How to Harness Your Board's Intellectual Capital”, Corporate Governance: The International Journal of Business in Society, 4(1), 5-23.

Pfeffer, J. (1972), "Size and Composition of Corporate Boards of Directors: The Organization and Its Environment”, Administrative Science Quarterly, 17(2), 218-228.

Shleifer, A. \& R. W. Vishny (1997), "A Survey of Corporate Governance”, The Journal of Finance, 52(2), 737-783.

Smith, N., V. Smith \& M. Verner (2006), "Do Women in Top Management Affect Firm Performance? A Panel Study of 2500 Danish Firms", International Journal of Productivity and Performance Management, 55(7), 569-593.

Truong, Q. \& Dang, C. (1998), "Effective Leadership in Joint Ventures in Vietnam: A Cross-Cultural Perspective”, Journal of Organizational Change Management, 11(4), 357-372.

U.S. Census Bureau (2008), “2007 NAICS Definitions”, retrieved on March 10, 2008, from: http://www.census.gov/eos/www/naics/htmls/4/448110.htm

Vietnam Ministry of Finance (2012), "Circular 121/2012/TT-BTC dated July 26, 2012 providing regulations on corporate governance applied to state-owned companies".

Wegge, J. et al. (2008), "Age and Gender Diversity as Determinants of Performance and Health in a Public Organization: The Role of Task Complexity and Group Size”, Journal of Applied Psychology, 93(6), 1301-1313.

Wooldridge, J. M. (2002), “Introductory Econometrics: A Modern Approach", $2^{\text {nd }}$ Ed., SouthWestern College.

Yermack, D. (1996), "Higher Market Valuation of Companies with a Small Board of Directors", Journal of Financial Economics, 40(2), 185-211. 